\title{
Importance of the Motivational Factors Affecting Employees Satisfaction
}

\author{
Gülten YURTSEVEN \\ Assist. Prof, Başkent University, Faculty of Commercial Sciences \\ Eskisehir yolu 20.km Ankara, TURKEY \\ Tel: 90-312-234-1010 E-mail: gkonuk@baskent.edu.tr \\ Ali HALICI (Corresponding author) \\ Başkent University, Faculty of Commercial Sciences \\ Eskisehir yolu 20.km Ankara, TURKEY \\ Tel: 90-312-234-1010 E-mail: ahalici@baskent.edu.tr
}

Received: August 8, 2011

doi:10.5539/ibr.v5n1p72
Accepted: October 31, 2011

Published: January 1, 2012

URL: http://dx.doi.org/10.5539/ibr.v5n1p72

\begin{abstract}
The purpose of this study is to determine the causes of motivational problems related to the duties of employees. The scope of the study involved 4 and 5 star rated hotels around Ankara region in Turkey. Twenty-seven different factors were analyzed regarding employees' attitudes towards "importance" and "satisfaction" within the workplace. Results reveal that employees give more importance to behavioral approaches. Also, findings show that the least important issues that employees care about are being uninformed about job policy and working beyond the normal working hours.
\end{abstract}

Keywords: Motivation, Job satisfaction, Motivational problems, Motivation in hotels

\section{Introduction}

The increasing importance of efficiency is a factor affecting the management of contemporary businesses in today's world. Therefore it is vital for today's administrators to examine various employee motivation methods and determine which is the most successful. A business will perform inefficiently if it does not effectively utilize its human resources.

There are many theories about motivation that will be discussed below. However, it is not possible to identify a specific theory that provides a single universal reality. Motivation is a complex concept influenced by numerous individual and situational variables.

Motivation is "a process which starts or improves organizational behaviors, encourages an ongoing activity and directs activities towards specific targets" (Madsen, p. 46). According to Robbins (2001), motivation is the processes that account for an individual's intensity, direction, and persistence of effort toward attaining a goal (Robbins, $p$. 156).

\subsection{Motivation Theories}

Current theories address different variables. Some are directed at explaining turnover and job satisfaction, while others emphasize productivity. The theories also differ in their predictive strength, e.g., Need Theories, Goal-Setting Theory, Reinforcement Theory, Equity Theory and Expectancy Theory (Robbins, 2001; Koçel, 1995; Scott, Mitchell $\&$ Terence, 1982).

\subsection{Job Satisfaction}

Job satisfaction is a general attitude towards one's job (Schermerhorn, Hunt \& Osborn 1997; Robbins, 2001). Motivation is a process of satisfying employees' different needs and expectations; therefore, administrators have to be aware of and analyze those unique, individual needs.

Administrators have the difficult task of actualizing performance above the current level of employees' and colleagues' performance. They have to increase employees' attention towards organizational targets and direct their behavior towards the achievement of corporate targets. 


\subsection{Motivation and Job Satisfaction in the Literature}

There are many studies that have analyzed the relationship between motivation and job satisfaction and its relationship between and among other related variables (George \& Jones, 1996; Newstrom \& David, 1993; Mullins, 1989). Low wages and salaries, physical working conditions, low-status positions and tiring jobs are among the common reasons that cause problems in service sector businesses. Also, the prejudice of not considering the job as an important duty or as a promising career exists among the employees.

There are various studies evaluating the link between culture and job satisfaction. Huang \& Van de Vliert (2003) showed that the link between intrinsic job characteristics and job satisfaction is stronger in richer countries, countries with better governmental social welfare programs, more individualistic countries, and smaller power distance countries. Probst, Martocchio, Drasgow \& Lawler(2000) predicted that the "empowerment and continuous improvement practices would be more congruent in some cultures than in others and that value congruence would result in job satisfaction based on the theoretical constructs of individualism-collectivism and power distance." Pellegrini \& Scandura (2006) used a structural, equation modeling approach to investigate relationships among leader-member exchange (LMX), delegation, paternalism and job satisfaction in Turkish business organizations. Results suggest that delegation might not be an effective management tool in the Middle Eastern context. Firestone, Garza, \& Harris (2005) examined the relationship between the Protestant work ethic (PWE) and job satisfaction and productivity in Mexico which has a highly collectivistic culture. Results indicate that those with higher PWE scores tend to gain a greater vote of confidence and respect from their workplace supervisors, which translated into higher assessments of their workplace productivity. Huang \& Van de Vliert (2004) showed that job level is positively related to job satisfaction in individualistic countries, but not in collectivistic countries. Moreover, the positive relationship between job level and job satisfaction holds only for jobs with much opportunity to use one's skills and abilities, especially in individualistic countries. Job level is even negatively related to job satisfaction in jobs with little opportunity to use one's skills and abilities in collectivistic countries. Thomas \& Pekerti (2003) examined the moderating affect of national culture on the relationship between job satisfaction and the exchange behaviors of employees.

Motivation and job-satisfaction area were determined (Milman, 1985; Standish, 1982; Noel, Hamel \& Bootman, 1982; Katzell \& Yankelovich, 1976). Research and theory on employee job satisfaction and well-being has increasingly concentrated on both intrinsic and extrinsic motivational factors. According to self-determination theory (Deci \& Ryan, 1985), autonomy, relatedness, and competence are three intrinsic psychological needs that, if fulfilled in the workplace, will lead to greater satisfaction, performance, and general well-being (Deci \& Ryan, 1985).

Another area of study is correlation between job satisfaction and motivational factors. Some of these studies questioned this relationship in different sectors. Tzeng (2002) showed that nurses have a work environment in which the work characteristics are known to be linked to job satisfaction and good outcomes. Becherer, Morgan \& Richard (1982) studied the relationship between job characteristics of industrial salespersons and motivation and satisfaction. Hunt M, Head TC and Sorensen PF, (1982) analyzed job characteristics, job satisfaction, motivation and the role of context variables using hospital pharmacists. Issues such as job characteristics, job-satisfaction, motivation and satisfaction with growth using a sample of industrial engineers. Wahba (1978) studied motivation, performance and job satisfaction of librarians. Influence of perceived job-enrichment and goal characteristics on employee satisfaction, motivation, and performance is another study topic researched by Maillet in 1994. According to Ma \& MacMillan (1999), workplace conditions positively affected teacher satisfaction. Of these conditions, administration control was the most important, followed by teaching competence and organizational culture.

Some other researchers analyzed the relationship between job satisfaction and various specific motivational factors. Pool (1997) examined the predictive values of substitutes of leadership, leadership behavior, and work motivation in relation to job satisfaction based on a self-report questionnaire. The results of independent regression analyses revealed that all but subordinate substitutes were significant predictors of job satisfaction. Tsai PCF, Yen YF, Huang LC and Huang IC (2007) revealed that the two criterion in job satisfaction "the relationship with colleagues" and "the relationship with the family" significantly influenced employees' motivation. Igalens \& Roussel (1999) examined how the elements of total compensation might influence work motivation and job satisfaction. Lawler EE and Hall DT (1970) investigated the relationship between job characteristics, job involvement, satisfaction, and intrinsic motivation. Cummings TG and Bigelow J (1976) studied the relationship among job satisfaction, job involvement and intrinsic motivation. Among the three-attitudinal variables, Chiu (2000) found that pay satisfaction and job satisfaction could mediate the effect of positive affectivity on work motivation. Ilardi BC, Leone D, Kasser $\mathrm{T}$ and Ryan RM's (1993) showed that both employee and supervisor ratings of intrinsic motivational factors were significantly related to work satisfaction, psychological health, and self-esteem, after controlling for the extrinsic 
factors of pay and job status. Orpen (1994) studied the interactive effects of work motivation and personal control on employee job-performance and satisfaction.

\section{The Study}

Based on the above literature search, the purpose of this study is to determine the causes of motivational problems related to the duties of personnel working in the hotels in Ankara. A selected 27 different factors were examined within the context of importance and satisfaction. The study also tried to determine which factors do the personnel consider as most important in its work environment and to what degree do those factors are satisfied.

This study was conducted in 4 and 5 star hotels situated in Ankara, Turkey. To insure the validity and reliability of the research, responses from as many 4 and 5 star-rated hotels as possible were used $(n=12$ for five star hotels and $n$ $=6$ for four star hotel). The survey was only administered to the housekeeping staff in the hotels because of the difficulty of contacting the full complement of staff in the hotels and the possibility of variations in the results of different departments. One of the five star hotels decline participation in the survey because it was about to be sold. In 2 of the five star hotels the results gathered were not included in the results because personal relationships existed between a number of researchers and this could have biased the results. Therefore the actual sample consisted of 9 five star hotels and 6 four-star hotels. The total population used was 177 permanent staff from the housekeeping departments of the hotels. The number of the staff participating in the survey was 144 , an $81.4 \%$ response rate.

For the purpose of collecting data in this survey, "the motivation problems" survey was used because it is well-known in management literature for its validity. The survey has two parts consisting of a total of 27 questions. In the first part the staffs were asked how important the various factors were, and in the second part they were asked how satisfactorily their employers performed in terms of these factors. Therefore, the importance given by the staff to the issued factors, and the satisfaction level achieved by the employing firm in terms of these factors regarding the employees were determined.

In the measurement of the survey questions, the 5-point Likert Scale was used. The scale reference points were: Importance Levels - "0" stands for "unimportant" and "4" stands for "very important"; and Satisfaction Levels - "0" stands for "not satisfactory at all" and "4" stands for "very satisfactory". In order to determine the demographic qualities of the respondents, five basic questions were added to the beginning of the survey.

The pilot study of the research was done in January 2004 using a randomly chosen hotel. The survey was administered by the researchers to insure that all participating staff answered the questions using the same terms. The personal interview method was used in order to provide the same understanding of the questions among all personnel and help attain reliable answers, particularly from lower-educated employees. All the survey questions were answered during lunchtimes or working hours. The Kendall's tau-c correlation coefficient was calculated in order to determine the relationship between the satisfaction level and the importance level given to the questions asked. The normal distributions of both variables were doubtful so the Wilcoxon Signed-Ranks Test, commonly used for comparing dependent pairs, was preferred. Both evaluations were utilized to calculate every question separately. The average, percentage calculation and standard deviation for every question were also determined.

\section{Research Findings}

Research findings are classified into three parts: The first section presents the demographic statistics; the second section presents the responses to the questions directed at discovering motivation problems; and the final section presents the relationships between the demographic qualities and the motivation problems.

\subsection{Demographic Findings}

According to the data from the first 6 (demographic) questions, the total number of staff participating from the four-star hotels was 59 (41.0\% of total respondents), and the total numbers of staff in five star hotels was 85 (59.0\%). Of the total respondents, $43.1 \%$ were and $56.9 \%$ were men. The completed levels of education were: 41 primary school graduates, 33 secondary school graduates, 56 high school graduates, and 13 university graduates. None of the staff members had a $\mathrm{PhD}$ or a Masters degree. It is evident that most of the staff were not university graduates $(90.9 \%)$ and the highest number of respondents were high school graduates $(39.2 \%) .91(63.2 \%)$ of the total participants were married and $53(36.8 \%)$ of them were single. The average age of staff participating in the survey was 32.1 years, and the average length of tenure was 6.5 years. The tenure statistics of the staff indicated a widespread distribution.

\subsection{The Data Related to the Motivational Problems}

There are 26 questions for determining the motivational problems in this research. Additionally, a general importance and satisfaction question was asked to assist in the total evaluation. Questions were evaluated according to the Likert Scale. 


\section{Insert Table 1 Here}

The evaluations of the questions are as follows:

- There is no relationship between the importance given for the salary earned and surveyed satisfaction levels of staff and no correlation between the salary levels and responses to the survey questions.

- The staff gave importance to job security, but the level of satisfaction they receive is low.

- The staff considered not to work extra hours important, but they usually must work extra hours.

- The staff thinks that social assistance is important, but they are not satisfied with the level given.

- The staff thinks that being rewarded is important, but the satisfaction level is low.

- The hotel staff thinks they should be appreciated for their performance, but they do not receive any appreciation.

- Hotel staffs are eager to participate in decision-making, but management does not allow them to participate in the process.

- Employees place importance on staffs' contribution in discussing company goals, but they do not have opportunities to contribute.

- Staff gives importance to not being informed about the general policies of the company but managers do not inform staff regarding companies' policies.

- Staffs want to utilize their abilities, but they do not have any opportunities.

- The staff desire to improve and develop their personal skills and abilities, but they do not get any chance to improve themselves in their companies.

- Hotel staffs want to be trained, but they do not have the opportunity.

- Staffs want to be authorized and take responsibility in the working areas, but they do not get these opportunities.

- Staffs want respect between co-workers, but it does not exist.

- Staffs think it is important to be respected because of their jobs, both in work and social life, but they feel their jobs do not receive proper respect.

- Staff place importance on being sufficiently qualified to utilize tools and materials, but they believe the tools and materials are not current and efficient.

- Staffs think good working conditions are a perquisite for increased, positive performance, but there is a great discrepancy between the current conditions and what they should be.

- Staffs receive no satisfaction in their relationship with their employers, but it is highly important to them.

- Staffs want to communicate with the managers easily, but they do not get the training or opportunities.

- Staff place importance in the managers' ability to mediate disagreements and arguments, but they do not see this being done.

- Staff place importance on good attitudes and behaviors from their managers when there are disagreements between the staff and clients, but do not experience this.

- Staffs want to work harmoniously with all groups/areas of the work place, but they do not experience this.

- Staff wishes to work co-operatively within their groups in the company, but do not have any satisfaction doing this.

- Staffs want their duties, authority and responsibilities to be clarified, but they are not.

- Staffs want job responsibilities to be equally distributed, but they are not.

- Staffs consider it important to be able to take holidays and vacations, but they are not able to take holidays and vacations easily.

- Staff generally give importance to attaining satisfaction in all areas, but indicated that they do not receive it.

\subsection{The Relationship between Demographic Characteristics and the Motivational Problems}

The differences between four and five star hotels were evaluated. In order to investigate the effect of each variable, correlations were calculated at $\mathrm{p}<.05$. A significant relationship between two characteristics is identified. First, there 
is a significant relationship between the rating of hotel and the level of job satisfaction $(p<0.05)$. The direction of this relation is positive and its force is weak $(0,18)$.

(Insert Table 2. here)

Clearly the staffs working in five star hotels receive more satisfaction than those working in four-star hotels.

The second significant relationship is between tenure and the level of job satisfaction $(\mathrm{p}<0.05)$. The relation has a medium force $(0,23)$. It is observed that there is a positive relationship between tenure and job satisfaction.

(Insert Table 3. here)

\section{Discussion of Findings}

According to the above results, the most important topics that concerned employees were getting on well with their colleagues and experiencing a positive and supportive attitude from their managers. These topics are based in the level of communication with colleagues or with managers. From the results, it is clear that the employees give more importance to behavioral approaches.

The less important issues that employees care about are being uninformed about job policy and working beyond regular working hours. Housekeeping personnel do not pay much attention to management policies. Employees feel distant from management, if their level of education is low and they do not see how to progress in their jobs. Hotels operate non-stop 24 hours per day, 365 days a year. Working hours for this industry are not fixed, especially during the busy seasons. Therefore, staffs often work overtime. The employees see this as a part of their obligation and do not expect extra compensation.

The employees give the same amount of importance to their salary and their job security. However, the level of satisfaction is low for job security. Housekeeping departments have one of the highest turnover rates in this sector. This clearly contributes to the level of importance given to job assurance. However, the relationships among co-workers and management often are more important to employees than job assurance and salary level.

Summarily, the conciliatory approach of the manager when a disagreement occurs with a customer, good relationships with their colleagues and collaboration are considered more important by employees.

The lowest satisfaction levels rank as follows: contributing to the determination of the management goals, rewarding for individual success and promoting personal progress. Salary level for the job, the possibilities for job training and job education follow these. The less important factors are appreciation for success, social aids like clothing and fuel support and health services and to have opinion about the decisions that are taken.

\section{Conclusion}

The level of satisfaction of the employees in 5 star hotels is higher. In Ankara, the 5 star hotels are more institutionalized than the other hotels. The magnitude of business affects the attitude of management. Therefore, at 5 star hotels' professional management comprehension is being adapted and the motivation of the employees has become more important. However, according to the results of this research, these areas are still not at the desired level.

Research regarding the employees' personal data, there is a positive relationship between the age of the worker and work satisfaction. The reason for the positive relationship is that as the workers age, their adaptation to the job increases. Conversely, young and new employees' expect excellent working conditions and desire quick promotions, but have a higher level of dissatisfaction when they start their jobs.

Through every area of this research, there is distinct correlation between the importance level and the satisfaction level. The employees were not satisfied regarding issues which are important for them. This shows that there are considerable motivational problems in the analyzed businesses. The basic reason for this is that the salaries and per diem rates are low in Turkey; therefore, the managers are not interested in the productivity of the employees. The rules for employees are well determined in the hotel sector. The price of not following the rules is quite heavy. Therefore, the managers feel no need to address motivational problems with their staff despite the need to increase service quality enough to make their hotels profitable and desirable. Further study should be done in other service areas to see if there are similarities to the above research.

\section{References}

Becherer, R. C., Morgan, F. W., \& Richards L. M. (1982). The job characteristics of industrial salespersons-relationship to motivation and satisfaction. Journal of Marketing, 46(4), 125-135.

Chiu, R. (2000). Does perception of pay equity, pay satisfaction, and job satisfaction mediate the effect of positive affectivity on work motivation? Social Behavior and Personality, 28(2), 177-184. http://dx.doi.org/10.2224/sbp.2000.28.2.177 
Cummings, T. G., \& Bigelow, J. (1976). Satisfaction, job involvement, and intrinsic motivation: An extension of Lawler and Hall's factor analysis. Journal of Applied Psychology, 61(4), 523-525. http://dx.doi.org/10.1037/0021-9010.61.4.523

Deci, E. L., \& Ryan, R. M. (1985). Intrinsic motivation and self-determination in human behavior. New. York: Plenum. ISBN 0306420228.

Firestone, J. M., Garza, R. T., \& Harris, R. J. (2005). Protestant work ethic and worker productivity in a Mexican brewery. International Sociology, 20(1), 27-44. http://dx.doi.org/10.1177/0268580905049908

George, J. M., \& Jones, G. R. (1996). Understanding and Managing Organizational Behavior. Reading. Massachusetts: Addison-Wesley Publishing Company.

Helphingstine, S. R., Head, T. C., \& Sorensen, P.F. (1981). Job characteristics, job-satisfaction, motivation and satisfaction with growth- a study of industrial-engineers. Psychological Reports, 49(2), 381-382. http://dx.doi.org/10.2466/pr0.1981.49.2.381

Huang, X. Van de Vliert, E. (2003). Where intrinsic job satisfaction fails to work: national moderators of intrinsic motivation. Journal of Organizational Behavior, 24(2), 159-179. http://dx.doi.org/10.1002/job.186

Huang, X. Van de Vliert, E. (2004). Job level and national culture as joint roots of job satisfaction. Applied Psychology, 53(3), 329-348. http://dx.doi.org/10.1111/j.1464-0597.2004.00174.x

Hunt, M., Head, T. C., Sorensen, P. F. (1982). Job Characteristics, job-satisfaction, motivation and the role of context variables-a study of hospital pharmacists. Psychological Reports, 51(2), 394. http://dx.doi.org/10.2466/ pr0.1982.51.2.394

Igalens, J., Roussel, P. (1999). A study of the relationship between compensation package, work motivation and job satisfaction. Journal of Organizational Behavior, 20(7), 1003-1025. http://dx.doi.org/10.1002/(SICI)1099-1379(199912)20:7<1003::AID-JOB941>3.0.CO;2-K

Ilardi, B. C., Leone, D. Kasser, T., \& Ryan, R. M. (1993). Employee and supervisor ratings of motivation-main effects and discrepancies associated with job-satisfaction and adjustment in a factory setting. Journal of Applied Social Psychology, 23(21), 1789-1805. http://dx.doi.org/10.1111/j.1559-1816.1993.tb01066.x

Katzell, R. A., \& Yankelovich, D. (1976). Pay vs. work motivation and job-satisfaction. Compensation Review, 8(1), 54-56. http://dx.doi.org/10.1177/088636877600800107

Lambert, S. J. (1991). The combined effects of job and family characteristics on the job-satisfaction, job involvement, and intrinsic motivation of men and women workers. Journal of Organizational Behavior, 12(4), 341-363. http://dx.doi.org/10.1002/job.4030120408

Lawler, E. E., Hall, D. T. (1970). Relationship of job characteristics to job involvement, satisfaction, and intrinsic motivation. Journal of Applied Psychology, 54(4), 305. http://dx.doi.org/10.1037/0021-9010.61.4.523

Ma, X. MacMillan, R. B. (1999). Influences of Workplace Conditions on Teachers' Job Satisfaction. The Journal of Educational Research, 93(1), 39-47. http://dx.doi.org/10.1080/00220679909597627

Madsen, K. B. (1968). Theories of Motivation. (4th ed.). Ohio: The Kest State University Press.

Maillet, L. J. (1984). Influence of Perceived job-enrichment and goal characteristics on employees satisfaction, motivation, and perfornance. PsychologicalReports, 54(1), 131-137. http://dx.doi.org/10.2466/pr0.1984.54.1.131

Milman, V. E. (1985). Working Motivation and job-satisfaction. Psikhologicheskii Zhurn., 6(5), 62-72.

Mullins, L. (1989). Management and Organizational Behavior. (2nd ed.). London: Pitman Pub.

Newstrom, J. W., \& Davis, K. (1993). Organizational Behavior: Human Behavioral Work. (9th ed.). New York: McGraw-Hill, Inc.

Orpen, C. (1994). Interactive effects of work motivation and personal control on employee job-performance and satisfaction. Journal of Social Psychology, 134(6), 855-856. http://dx.doi.org/10.1080/00224545.1994.9923021

Pellegrini, E. K., \& Scandura, T. A. (2006). Leader-member exchange (LMX), paternalism, and delegation in the Turkish business culture: An empirical investigation. Journal of International Business Studies, 37(2), 264-279. http://dx.doi.org/10.1057/palgrave.jibs.8400185

Pool, S. W. (1997). The relationship of job satisfaction with substitutes of leadership, leadership behavior, and work motivation. The Journal of Psychology, 131(3), 271-283. http://dx.doi.org/10.1080/00223989709603514

Robbins, S. (2001). Organizational Behavior. (9th ed.). New Jersey: Prentice Hall Inc.

Robert, C., Probst, T. M., Martocchio, J. J., Drasgow, F., \& Lawler, J. J. (2000). Empowerment and continuous 
improvement in the United States, Mexico, Poland, and India: Predicting fit on the basis of the dimensions of power distance and individualism. Journal of Applied Psychology, 85(5), 643-648. http://dx.doi.org/10.1037/0021-9010.85.5.64

Schermerhorn, J. R., Hunt, Jr.J. G., \& Osborn, R. N. (1997). Organizational Behavior. (6th ed.). New York: John Wiley \& Sons, Inc.

Scott, W., Mitchell, G., \& Terence, R. (1972). Organization Theory. A Structural and Behavioral Analysi. Illinois: Richard D. Irwin, Inc.

Standish, R. C. (1982). Job-satisfaction and Motivation. American Journal of Hospital Pharmacy, 39(9), 1460.

Thomas, D. C., \& Pekerti, A. A. (2003). Effect of culture on situational determinants of Exchange behavior in organizations-a comparison of New Zealand and İndonesia. Journal of Cross-Culturel Psychology, 34(3), 269-281. http://dx.doi.org/10.1177/0022022103034003002

Tsai, P. C. F., Yen, Y. F., Huang, L. C., \& Huang, I. C. (2007). A study on motivating employees' learning commitment in the post-downsizing era: Job satisfaction perspective. Journal of World Business, 42(2), 157-169. http://dx.doi.org/10.1016/j.jwb.2007.02.00

Tzeng, H. M. (2002). The influence of nurses' working motivation and job satisfaction on intention to quit: an empirical investigation in Taiwan. International Journal of Nursing Studies, 39(8), 867-878. http://dx.doi.org/10.1016/S0020-7489(02)00027-5

Wahba, S. P. (1978). Motivation, performance and job satisfaction of librarians. Law Library Journal, 71(2), 270-278.

Table 1. The Average Scores of Satisfaction and Importance of the Factors

\begin{tabular}{|c|c|c|c|c|c|c|}
\hline \multirow[t]{2}{*}{ Questions } & \multirow{2}{*}{$\frac{\mathrm{L} / \mathrm{S}}{\text { Mean }}$} & \multirow{2}{*}{$\frac{\mathrm{L} / \mathrm{I}}{\text { Mean }}$} & \multicolumn{2}{|c|}{ Tau-c Corr. Coef. } & \multicolumn{2}{|c|}{$\begin{array}{c}\text { Wilcoxon } \\
\text { Signed R.T. }\end{array}$} \\
\hline & & & Value & Sig. & Z-value & Sig. \\
\hline 1. The level of salary & 3,55 & 2,18 & $0,022 \pm 0,053$ & $\mathrm{n} / \mathrm{s}$ & $-8,687$ & $\mathrm{~s}$ \\
\hline 2. Job security & 3,55 & 2,24 & $0,101 \pm 0,490$ & $\mathrm{~s}$ & $-8,089$ & $\mathrm{~s}$ \\
\hline 3. Extra working hours & 2,87 & 2,14 & $0,164 \pm 0,068$ & $\mathrm{~s}$ & $-4,729$ & $\mathrm{~s}$ \\
\hline 4. Social aid other than the salary & 3,44 & 2,15 & $0,073 \pm 1,376$ & $\mathrm{n} / \mathrm{s}$ & $-7,462$ & $\mathrm{~s}$ \\
\hline 5. Reward for success (apart from the salaries) & 3,26 & 1,83 & $0,020 \pm 0,055$ & $\mathrm{n} / \mathrm{s}$ & $-7,552$ & $\mathrm{~s}$ \\
\hline 6. Appreciation for success (Moral award) & 3,45 & 2,06 & $-0,004 \pm 0,057$ & $\mathrm{n} / \mathrm{s}$ & $-7,526$ & $\mathrm{~s}$ \\
\hline 7. Participation to the decisions & 3,19 & 2,24 & $0,205 \pm 0,063$ & $\mathrm{~s}$ & $-6,832$ & $\mathrm{~s}$ \\
\hline 8. Participation in the determination of the aims & 2,61 & 1,52 & $0,217 \pm 0,067$ & $\mathrm{~s}$ & $-6,578$ & $\mathrm{~s}$ \\
\hline 9. Uninformed about the common policy & 2,86 & 2,01 & $0,319 \pm 0,061$ & $\mathrm{~s}$ & $-5,976$ & $\mathrm{~s}$ \\
\hline 10. Being opportunity of using personal skills actively & 3,44 & 2,40 & $0,125 \pm 0,054$ & $\mathrm{~s}$ & $-7,300$ & $\mathrm{~s}$ \\
\hline 11. Possibility for career progress and development & 3,40 & 1,91 & $0,042 \pm 0,052$ & $\mathrm{n} / \mathrm{s}$ & $-7,918$ & $\mathrm{~s}$ \\
\hline 12. Availability of internal training programs & 3,43 & 2,18 & $0,047 \pm 0,054$ & $\mathrm{n} / \mathrm{s}$ & $-7,299$ & $\mathrm{~s}$ \\
\hline 13. Level of assigned responsibility & 3,64 & 2,84 & $0,107 \pm 0,043$ & $\mathrm{~s}$ & $-6,329$ & $\mathrm{~s}$ \\
\hline 14. Esteem and prestige between colleagues & 3,45 & 2,61 & $0,191 \pm 0,047$ & $\mathrm{~s}$ & $-6,278$ & $\mathrm{~s}$ \\
\hline 15. Esteem and prestige of the work in society & 3,32 & 2,35 & $0,180 \pm 0,054$ & $\mathrm{~s}$ & $-6,633$ & $\mathrm{~s}$ \\
\hline 16. Adequacy of the material, equipment exc. & 3,49 & 2,71 & $0,190 \pm 0,053$ & $\mathrm{~s}$ & $-6,497$ & $\mathrm{~s}$ \\
\hline 17. Work conditions & 3,50 & 2,73 & $0,120 \pm 0,052$ & $\mathrm{~s}$ & $-5,914$ & $\mathrm{~s}$ \\
\hline 18. Attitudes of managers towards relationships & 3,63 & 2,95 & $0,132 \pm 0,048$ & $\mathrm{~s}$ & $-6,004$ & $\mathrm{~s}$ \\
\hline 19. Possibilities discussion with managers & 3,57 & 2,95 & $0,192 \pm 0,051$ & $\mathrm{~s}$ & $-5,472$ & $\mathrm{~s}$ \\
\hline 20. Conciliatory approaches (among employees) & 3,48 & 2,91 & $0,216 \pm 0,055$ & $\mathrm{~s}$ & $-5,030$ & $\mathrm{~s}$ \\
\hline 21. Conciliatory approaches (customers-employees) & 3,48 & 3,18 & $0,330 \pm 0,053$ & $\mathrm{~s}$ & $-3,553$ & $\mathrm{~s}$ \\
\hline 22. Accord between employees & 3,67 & 3,15 & $0,187 \pm 0,045$ & $\mathrm{~s}$ & $-5,633$ & $\mathrm{~s}$ \\
\hline 23. Collaboration between employees & 3,60 & 3,11 & $0,245 \pm 0,044$ & $\mathrm{~s}$ & $-5,070$ & $\mathrm{~s}$ \\
\hline 24. Clarification of job responsibilities and authority & 3,57 & 2,91 & $0,195 \pm 0,054$ & $\mathrm{~s}$ & $-6,333$ & $\mathrm{~s}$ \\
\hline 25. Fairness of job distribution & 3,57 & 2,77 & $0,213 \pm 0,044$ & $\mathrm{~s}$ & $-6,232$ & $\mathrm{~s}$ \\
\hline 26. Receipt of leave and holiday rights & 3,58 & 2,87 & $0,115 \pm 0,050$ & $\mathrm{~s}$ & $-5,648$ & $\mathrm{~s}$ \\
\hline 27. Level of job satisfaction for the employees & 3,57 & 2,57 & $0,115 \pm 0,051$ & $\mathrm{~s}$ & $-7,594$ & $\mathrm{~s}$ \\
\hline
\end{tabular}

$(\mathrm{p} \leq .05)$ 
Table 2. Symmetric Measures of hotel rating and the level of job satisfaction

\begin{tabular}{|l|l|c|c|c|c|}
\hline \multicolumn{2}{|l|}{} & Value & $\begin{array}{l}\text { Asymp. Std. } \\
\text { Error(a) }\end{array}$ & Approx. T(b) & Approx. Sig. \\
\hline Interval by Interval & Pearson's R &, 178 &, 081 & 2,144 &, $034(\mathrm{a})$ \\
\hline Ordinal by Ordinal & Spearman Correlation &, 167 &, 082 & 2,016 &, 046 (a) \\
\hline N of Valid Cases & 143 & & & \\
\hline
\end{tabular}

(a) Based on normal approximation.

Table 3. Symmetric Measures of tenure and the level of job satisfaction

\begin{tabular}{|l|l|c|c|c|c|}
\hline \multicolumn{2}{|l|}{} & Value & $\begin{array}{c}\text { Asymp. Std. } \\
\text { Error(a) }\end{array}$ & Approx. T(b) & Approx. Sig. \\
\hline Interval by Interval & Pearson's R &, 230 &, 078 & 2,801 &, $006(\mathrm{a})$ \\
\hline Ordinal by Ordinal & Spearman Correlation &, 221 &, 083 & 2,677 &, $008(\mathrm{a})$ \\
\hline N of Valid Cases & 142 & & & \\
\hline
\end{tabular}

(a) Based on normal approximation. 